\title{
Human Resource Management Practices in Listed Firms in Sri Lanka
}

\author{
D. K. Sanjeewa Serasinghe \\ And \\ H.H.D.N.P.Opatha
}

\begin{abstract}
The objective of this research paper was to investigate whether size and age of listed firms relate to systematic use of HRM practices being followed by those firms and a significant difference exists between local firms and multinational firms operating in Sri Lanka with regard to systematic use of HRM practices. Three hypotheses were formulated using deductive approach. The study was conducted relating to all listed firms numbering 248, which were listed in the Colombo Stock Exchange. Type of investigation was correlational and it was cross-sectional in time horizon. The unit of analysis of this study was at firm level. The structured survey was administered to cover all the firms and human resource managers worked as the respondents on behalf of the firms. However data were possible to be collected from 66 managers representing 66 firms. In order to test the first and second hypotheses that were concerned with relationships of size and age with systematic use of HRM practices the Pearson Product-Moment Correlation technique was applied. The third hypothesis was concerned with difference between multinational firms and local firms with regard to systematic use of HRM practices and Independent Sample T test was the appropriate technique to test the validity of the hypothesis. The results of the study showed a significant difference existing between local firms and multinational firms operating in Sri Lanka with regard to systematic use of HRM practices. However the study revealed that size of the firm and the degree of systematic use of HRM practices and also age of the firm and the degree of systematic use of HRM practices are not significantly and positively related. Implication of the findings is that irrespective of the size of the firm and the age of the firm it is possible to establish good practices of Human Resource Management which contribute to provide the organization with a more appropriate and contended employee force that gives the maximum contribution to its success. In this context, top management support and employment of right personnel who specialize in HRM may be more important in enhancing the systematic use of HRM practices in firms.
\end{abstract}

Key words: Age, Human Resource Management Practices, Ownership, Size, Systematic Use

\section{Introduction}

Socio-economic development of Sri Lanka heavily depends on success and progress of success of organizations including listed firms. Human Resource Management (HRM), 
which is one of the most important functional fields of Organizational Management, is a sine qua non of success and progress of success of organizations at the micro level and socio-economic development of Sri Lanka in a competitive world market at the macro level. The term 'HRM' is concerned with human resources; functions; and goals. It refers to efficient and effective utilization of human resources to achieve organizational goals through the functions of human resource planning, staffing, human resource development, rewards, health and safety, employee relations and so on. Quality of HRM in an organization depends heavily on systematic use of HRM practices. As far as Sri Lanka is concerned, there is a serious need of systematizing HRM functions of organizations so as to realize the potential impact on achieving organizational success.

There are theoretical explanations or arguments (Glueck, 1978; Glueck, 1979; Ivancevich, 1992) in respect of the relationship between systematic use of HRM practices and the size of the organization and the age of the organization. It seems that there is a gap in the empirical knowledge available, in particular in Sri Lankan context, about testing the relationship between systematic use of HRM practices and the size of the firm, the relationship between systematic use of HRM practices and the age of the firm and difference between multinational firms and local firms with regard to systematic use of HRM practices. This paper focuses on addressing the following three research questions:

1. Is systematic use of HRM practices related to size of the firms?

2. Is systematic use of HRM practices related to age of the firms?

3. Is there a significance difference between local firms and multinational firms operating in Sri Lanka with regard to systematic use of HRM practices?

The objective of the paper is to investigate whether size and age of the firms relate to systematic use of HRM practices being followed by those firms and a significant difference exists between local firms and multinational firms operating in Sri Lanka with regard to systematic use of HRM practices.

\section{Research Framework}

HRM Practices refers to human resource manager's perceived degree of systematic use of HRM practices being followed by the particular firm. From a traditional functional perspective, HRM practices of a firm include job design, job analysis, human resource planning, recruitment, selection, hiring, induction, performance evaluation, pay and incentives management, training and development, welfare management, management of employee movements, health and safety management, discipline management, grievance handling, employee and labour relations (Beach, 1985; Schular and Youngblood, 1986; Bernardin and Russell, 1993; Werther and Davis, 1994; Opatha, 1995; Armstrong, 1998; Mathis and Jackson, 2000; and Dessler, 2005). As far as this study is concerned, only six HRM functions were considered and they included recruitment, selection, training and development, performance evaluation, grievance handling and discipline administration. Reasons for selection of these functions were their popularity in Sri Lankan practice, general consideration as major functions and of course parsimony. The working definition of a HRM function comprises of three distinct aspects: policy, procedure and practice. These aspects are perceived as reflective of the realities of a particular HRM 
practice, and therefore the three aspects are required to examine systematic use of HRM practices.

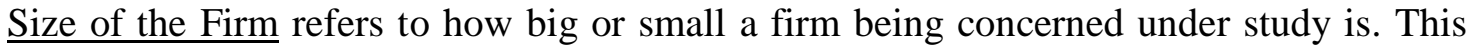
variable is not a perception and it is the amount of the firm in terms of employees. It is assumed that the number of employees determines the greatness of a firm in amount. It is argued that size of the firms influences systematic use of HRM practices. It is generally believed that a firm where many employees are working will have to systematize HRM function. It cannot properly run the business by using ad hoc HRM practices. In case of a small firm, the manager can do managing his/her subordinates by using informal recruitment, selection, induction, performance evaluation and training. There is no need of more sophisticated processes to be applied to a small organization. Also, it is more likely that a small organization is not in a position of affording a serious separate department for HRM functional field of Management led by a qualified human resource manager who is assisted by several HRM personnel. In contract, a large organization is in a good position to establish a separate department with a qualified staff. The larger the organization, the more extensively planned and evaluated will be its recruiting functions (Glueck, 1978). The larger the organization, the more likely is it for selection to follow a systematic-semirational procedure which involves most selection steps or techniques (Glueck, 1979). Larger organizations are more likely to use sophisticated selection techniques (Ivancevich, 1992). Whether the firm has a more systematized HRM or not depends on its size. The larger the organization, the more systematic HRM practices are. Based on these arguments, the first hypothesis of this study is as follows:

Hypothesis 1: Perceived systematic use of HRM practices of a firm is significantly and positively related to its size.

Age of the Firm refers to the number of years since the particular firm was commenced. It indicates the number of years that the firm has engaged in its business in the corporate world. In other words how old the firm is. This variable is also not a perception and it is the number of years of the firm since its birth. Compared with a firm with lesser age a firm with higher age has more likely better or more sophisticated HRM practices. The reason is better learning due to more experience. It is believed generally that the firm with many years of experience in the business is in a position of applying advanced and complex methods of HRM than a firm with a few years of experience. Whether the firm has a more systematized HRM or not depends on its age. The higher is the age of the firm, the more systematic is the HRM of the firm. Based on these arguments, the second hypothesis of this study is formulated as follows:

Hypothesis 2: Perceived systematic use of HRM practices of a firm is significantly and positively related to its age.

Ownership of the Firm refers to state of owning a firm. It means whether the firm is a local firm or a multinational firm. Local firm belongs to Sri Lanka where its business is registered. A multinational firm does not belong to Sri Lanka and it is headquartered in another country. Generally multinational firms are larger than local firms in terms of size. 
Also multinational firms are higher than local firms in terms of age generally. Multinational firms use successfully sophisticated management staffing techniques and their systematic use of HRM practices is higher compared with local firms (in Greece) (Papalexandris, 1992). Definitely multinational firms are greater than local firms in terms of learning through experience and they are better financially to utilize more qualified personnel in HRM. A multinational firm will have to face severe international competition, to meet various laws and requirements of host governments, face and bargain with various demands of different trade unions and manage third country nationals, host country nationals and expatriates. These challenges necessitate formal and systematic HRM policies, procedures and practices. It is argued that systematic use of HRM practices being applied by multinational firms is greater than that of HRM practices being applied by local firms. The above arguments lead to formulate a hypothesis as follows:

Hypothesis 3: There is a significant difference between local firms and multinational firms operating in Sri Lanka in respect of perceived systematic use of HRM practices.

Relevant schematic diagram is shown in figure-1. Systematic use of HRM practices is labeled as the dependent variable as the researchers are primarily interested in that. Size of the firm, age of the firm and ownership of the firm are labeled as independent variables as they are assumed to have an influence on the dependent variable, i.e. systematic use of HRM practices.

\section{Figure: 1 Schematic Diagram of the Research Framework}

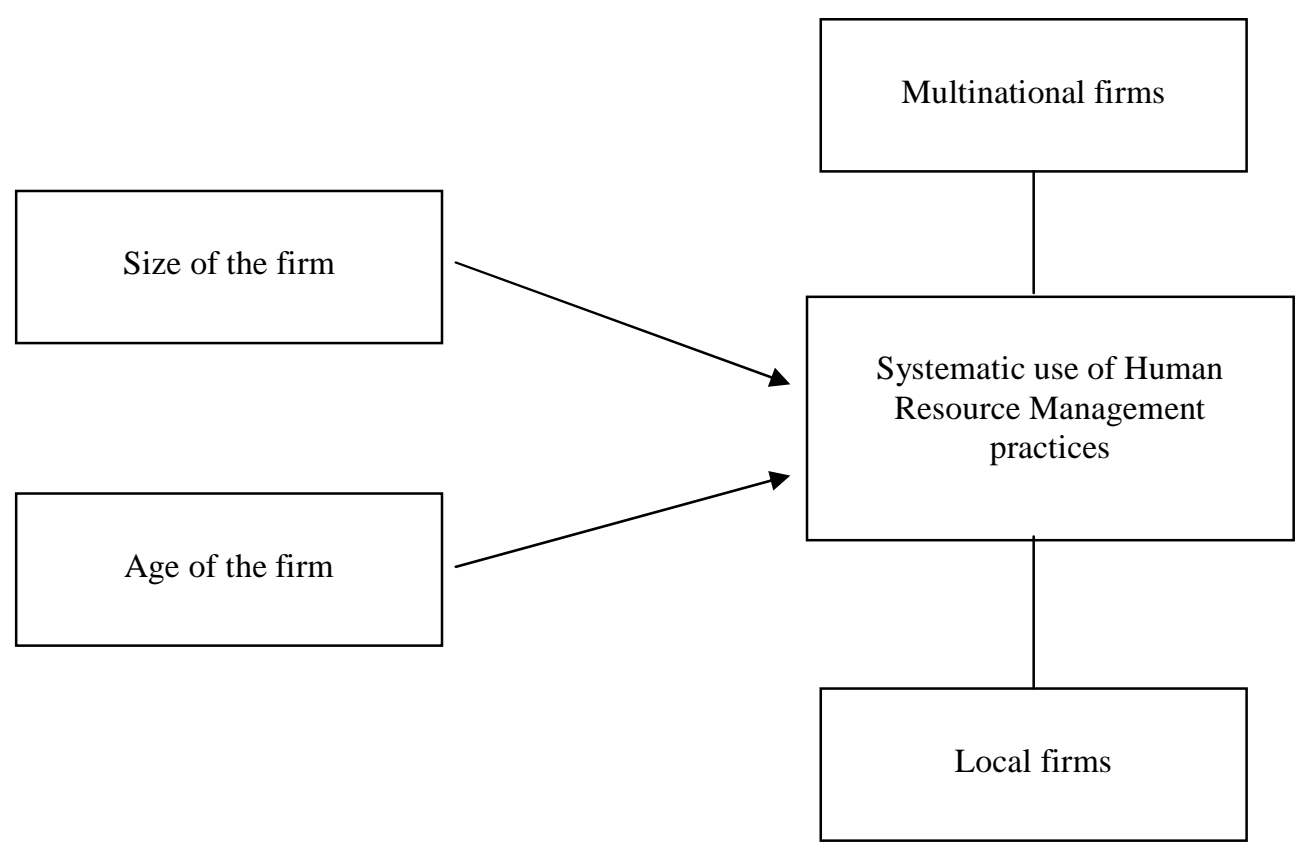




\section{Study Design}

\section{Method}

The researchers were interested in investigating whether size and age of the firms relate to systematic use of HRM practices being followed by those firms and a significant difference exists between local firms and multinational firms operating in Sri Lanka with regard to systematic use of HRM practices, rather than establishing definite cause $\rightarrow$ effect relationships among the variables. The type of investigation of this study was, therefore, correlational rather than causal. Because this study attempted to analyse the relationships and difference between the dependent variable and the independent variables, this study was analytical in nature or purpose. Because the data for this study were collected at a single point in time the study was cross-sectional in time horizon (Sekaran, 1999; Zikmund, 2000). This was an appropriate strategy when the main focus of the study was considered. In order to achieve objectives of the study, a self-administered questionnaire was used to collect data. Hence the researcher interference on normal flow of events was minimal. Population of the study consisted of all the listed firms (in the Colombo Stocks Exchange) in Sri Lanka and the number was 248. The structured survey questionnaire was sent to all the listed firms but only 66 firms responded within the time given (five weeks) giving a response rate of 26.6 per cent. Unit of analysis was at firm level: the human resource manager was the respondent on behalf of the firm.

\section{Measures}

HRM Practices: The perceived degree of systematic use of each HRM function was operationalised into three dimensions i.e., policy, procedure and practice. Then, each dimension was operationalised into several elements based on literature. Question items were developed in relation to elements identified. As six HRM practices, i.e. recruitment, selection, training and development, performance evaluation, grievance handling and discipline administration, six sub instruments were developed with regard to the variable of HRM practices. Each sub instrument had question items to tap the dimensions and elements of each HRM function and the responses to the questions were elicited on a 7point scale of 'strongly agree, agree, slightly agree, neutral, lightly disagree, disagree, and strongly disagree' or 'very high extent, high extent, slightly high extent, neutral, slightly low extent, low extent, and very low extent'. Weightages or values of 7,6,5,4,3,2 and 1 were given to these responses taking the direction of the question items (whether they were negative or positive as far as systematic use of each function was concerned) into account. Exhibit 1 gives sources of relevant literature used to develop the sub instruments. Finally a composite index was developed for the variable of HRM practices by applying the holistic approach. The final instrument to measure HRM practices had 98 questions. Level of measurement of the variable was interval. Appendix (given at the end of the paper) shows figures giving dimensions and elements of the six constructs (six HRM functions).

Exhibit: 1 Sources of Literature of Sub Instruments of HRM Practices

\begin{tabular}{|l|l|}
\hline $\begin{array}{l}\text { Sub Instrument (Dimensions and } \\
\text { Elements) }\end{array}$ & Relevant Source/s \\
\hline Recruitment & David, 1984; Opatha, 1995; Noe, 2003; \\
\hline Selection & David, 1984; Opatha, 1995; Noe, 2003; \\
\hline
\end{tabular}




\begin{tabular}{|l|l|}
\hline Training and Development & $\begin{array}{l}\text { David, 1984; Opatha, 1995; Aswathappa, } \\
\text { 2003; Noe, 2003; Dessler, 2005 }\end{array}$ \\
\hline Performance Evaluation & Mithani and Opatha, 2000; Opatha, 2005 \\
\hline Grievance Handling & Opatha, 1994; Opatha, 2002; Opatha, 2005 \\
\hline Discipline Administration & Opatha and Mithani, 2000; Opatha, 2005 \\
\hline
\end{tabular}

Size of the Firm: The variable of size of the firm was measured through the use of one direct question. The question dealt with number of employees with a 5-point scale of 'less than 500 employees, 501-1000 employees, 1001-1500 employees, 1501-2000 employees and more than 2000 employees'. Level of measurement of the variable was interval. The firms which had less than 500 employees were assigned with one point, two points were assigned to the firms with employees between $501-1500$, firms which had a range of $1001-1500$ employees were given three points, the firms which had a range of 1501 - 2000 employees were given four points, and finally five points were given to the firms which had more than 2000 employees.

Age of the Firm: One direct question was framed to measure the variable of age of the firm. The question dealt with number of years in business with a 5-point scale of 'less than 5 years, between 6 and 10 years, between 11 and 15 years, between 16 and 20 years, and more than 20 years'. Interval was the level of measurement of the variable. Points $1,2,3,4$,and 5 were given to the levels of the scale respectively.

Ownership of the Firm: This variable's level of measurement was nominal and it was measured through the use of one direct question that was in respect of whether the particular firm was local or multinational. For the purpose of analysis, number one was assigned to 'local firm' while number 2 was assigned to 'multinational firm'.

\section{Validity and Reliability}

The kinds of evidence in support of content validity involve (1) the judgment of those who construct the instrument or other experts familiar with the subject area; (2) detailed definition or conceptualisation and operationalisation of the behavioral domain or universe of interest; and (3) indirect way-high internal consistency reliability (Walsh and Betz, 1995; and Sekaran, 1999). These three requirements were satisfactorily met and therefore, content validity is assured. The dimensions and elements of the concept of Human Resources Management practices were delineated carefully basing on the literature and there are 98 questions that tap all the dimensions and elements identified with regard to each selected HRM function. A careful attempt was made by the researchers in constructing the instruments to consider what the phenomena were being studied, what the research objectives were, what the hypotheses formulated were and what the dimensions and elements which had been devised for the variables were. Consequently the instruments provided an adequate coverage of the phenomenon of HRM practices (selected for the study). Other variables of the study, i.e. size of the firm, age of the firm and ownership were not constructs.

In order to test the external aspect of the reliability of the instrument of HRM practices the test-retest method was used. With test-retest, reliability was obtained by 
administering the instrument to the same people on two different occasions. A two-week time interval between the two administrations was chosen to minimise the memory effects and the likelihood of true rating changes. Test-retest data were collected from 10 managers (firms) who were selected as per convenient sampling method. The test-retest co-efficient was 0.92. It suggested that the instrument possessed an adequate degree of external reliability. For testing the internal aspect (interitem consistency) of the reliability of the instruments developed to measure each selected function of HRM practices the Cronbach's coefficient alpha was used. The Cronbach's alpha values of the sub instruments measuring recruitment, selection, training and development, performance evaluation, grievance handling and discipline administration were $.92, .93,91,96,95$, and 94 respectively suggesting a good interitem reliability of each sub instrument. This was not applied for the other variables, as they had no several question items.

\section{Techniques of Data Analysis}

There were three hypotheses of the study. First hypothesis and second hypothesis were about relationships between two variables, and hence the Pearson Product-Moment Correlation technique was used. As the third hypothesis was about testing a difference between two groups with regard to one variable, Independent Sample T Test was applied. There was a need of exploring the data for normality and linearity, as the correlation tests were parametric. Exploration of the data revealed meeting of the conditions reasonably.

\section{Results}

The first hypothesis formulated for the study was that perceived systematic use of HRM practices of a firm is significantly and positively related to its size. The relevant null hypothesis is stated as that there is no relationship between perceived systematic use of HRM practice of a firm and size of the firm. For the purpose of testing the hypothesis the appropriate statistical test was Pearson Product Correlation Coefficient. Desired level of significant level is 0.05 . As the formulated alternative hypothesis is directional one-tailed test was used. The results of the correlation test are given in the following table.

Table: 1 Correlation between HRM Practices and Size of the Firm

\begin{tabular}{l|l} 
Pearson correlation coefficient & 0.127 \\
Significant (One-tailed) & 0.308 \\
N & 66 \\
\hline
\end{tabular}

According to the table the found Pearson Correlation Coefficient is 0.127 suggesting that there is a very weak positive relationship between the HRM practices of the firm and size of the firm. As the significant value (0.308) is greater than the desire level of significance (0.005), the found correlation coefficient $(0.127)$ is not statistically significant. Hence alternative hypothesis can not be accepted. In other words there is no statistical evidence to reject the null hypothesis. Therefore, there is no statistical evidence to claim that there is a significant relationship between HRM practices of the firm and size of the firm.

The second hypothesis of the study was that perceived systematic use of HRM practices of a firm is significantly and positively related to its age. The relevant null hypothesis is 
stated as that there is no relationship between perceived systematic use of HRM practice of a firm and age of the firm. To test the second hypothesis too the appropriate statistical test was Pearson Product Correlation Coefficient. Desired level of significant level is 0.05 . As the formulated alternative hypothesis is directional one-tailed test was used. The results of the correlation test are given in the following table.

Table: 2 Correlation between HRM Practices and Age of the Firm

\begin{tabular}{|l|c|}
\hline & \\
Pearson correlation coefficient & 0.193 \\
Significant (One-tailed) & 0.060 \\
$\mathrm{~N}$ & 66 \\
\hline
\end{tabular}

As per table 2 the Pearson Correlation Coefficient between the two variables is 0.193 suggesting that there is a very weak positive relationship between HRM practices and size of the firm. As the desire level of significance (0.005) is smaller than the significant value $(0.060)$, the found correlation coefficient $(0.193)$ is not statistically significant. Hence the alternative hypothesis can not be accepted. There is no statistical evidence to reject the null hypothesis. In other words there is no statistical evidence to substantiate the alternative hypothesis that perceived systematic use of HRM practices of a firm is significantly and positively related to its age.

The third hypothesis formulated for this study was that there is a significant difference between local firms and multinational firms operating in Sri Lanka in respect of HRM practices. Relevant null hypothesis is that there is no difference between local firms and multinational firms operating in Sri Lanka in respect of HRM practices. For the purpose of the testing the hypothesis the appropriate statistical technique was Interdependent Sample T Test and the desire level of significance is 0.05 (95\% confident level). As the alternative hypothesis was a non directional one, two-tail test was applied. The following table shows the results of the independent sample test.

Table: 3 Independent Sample $T$ Test of Ownership of the Firm and Human Resources Management Practices

\begin{tabular}{|l|c|}
\hline & Value \\
Mean - Local & 23 \\
Mean - Multinational & 42 \\
$\mathrm{t}$ (Equal variances assumed) & -9.099 \\
$\mathrm{t}$ (Equal variances not assumed) & -17.636 \\
Mean difference & 19 \\
df (degree of freedom) & 64 \\
Sig (2-tailed) & 0.0005 \\
\hline
\end{tabular}

When considered the mean value there is a difference descriptively. It suggests that systematic use of Human Resources Management practices of multinational firms is 
greater than that of local firms. In order to find out whether this difference is statistically significant or not Independent Sample $\mathrm{T}$ Test was used. Results of the independent sample T Test show that Levene's test for equality of variances is significant with $\mathrm{F}=$ 80.261 ( $\mathrm{sig} .0005$ ). It is suggested that the null hypothesis that the two population variances are equal can not be accepted. Therefore, $\mathrm{T}$ Test for equal variances are not assumed was considered (Norusis, 1997). The T value for equal variances not assumed is -17.636 that was significant at $99 \%$ confident level ( $\mathrm{sig}=0.0005$ is less than 0.01 ). Since the $t$ value is statistically significant, the relevant null hypothesis is rejected. Therefore the alternative hypothesis is accepted. Thus there is statistical evidence to claim that the degree of systematic use of Human Resources Management practices of multinational firms is significantly different from that of local firms. In fact the degree of systematic use of Human Resource Management practices of multinational firms is greater than that of local firms.

\section{Discussion}

There is no statistical evidence to accept the first hypothesis (perceived systematic use of HRM practices of a firm is significantly and positively related to its size) and it was rejected. This suggests that there is no relationship between the firm size and the systematic use of Human Resources Management practices. As hypothesized, it is likely that size of the firm does not influence the HRM practices. This may be due to the reason that top management philosophy of HRM and importance given by the top management influence the firm to follow more systematic or unsystematic HRM practices. Or there may be other factors that influence the systematic use of HRM practices of the firm rather than size of the firm. If Nestle is taken, it is a very large multinational company operating closely in hundred countries worldwide and in Sri Lanka too. In Sri Lanka the employee strength of that company is less than 500 but comparatively the Human Resources management practices are very good. Similarly if Coca Cola Company in Sri Lanka is taken it has less than 500 employees but its systematic use of Human Resource Management practices is high. When looking at large firms operating in Sri Lanka such as Uni-Leaver, Hayleys, etc there are comparatively good Human Resources Management practices. Thus the study does not show any empirical evidence to show significant relationship between size of the firm and the firm's systematic use of HRM practices.

The second hypothesis (perceived systematic use of HRM practices of a firm is significantly and positively related to its age) was too rejected according to the results of the study. There is no statistical evidence to substantiate hypothesized relationship between the two variables. If the finding is taken as true, there are other factors which influence the systematic use of HRM practices. It may be that if a firm with age of fewer years has a manager of HRM who is a real HRM expert and a person of high integrity is in a position of systematizing HRM practices. Firms which are below 10 years and operating in Sri Lanka such as Suntel, MAS Holdings, and etc, have been practicing more systematic Human Resources Management practices comparatively and firms which are operating in Sri Lanka more than 10 years such as Nestle, Coca Cola, and etc also have comparatively good practices of Human Resources Management. Hence it was found that there is on relationship between age of the firm and systematic use of Human Resources 
Management practices. It is argued that if background of the firm is good, if the top management commitment towards the Human Resources Management practices is good, it is likely for the firm to have good practices in HRM irrespective of age.

The third hypothesis (there is a significant difference between local firms and multinational firms operating in Sri Lanka in respect of HRM practices) was substantiated as far as the data of this study are concerned. It suggests that the Human Resources Management practices in multinational firms are better than that of local firms. Most of the firms in developed countries have the best management practices comparatively to the firms in developing countries. Since Sri Lanka belongs to the category of developing countries, obviously the degree of Human Resources Management practices can be lower than developed countries. Many multinational firms operating in Sri Lanka are from developed countries, hence obviously the Human Resources Management practices in multinational firms operating in Sri Lanka are better than that of Sri Lankan firms.

\section{Conclusion}

The results of the study lead to confirm the prediction made by researchers regarding a significant difference that exists between local firms and multinational firms operating in Sri Lanka with regard to systematic use of HRM practices. However the study revealed that there is no significant relationship between size of the firm and the degree of systematic use of HRM practices and also there is no significant relationship between age of the firm and the degree of systematic use of HRM practices. Implication of the findings is that irrespective of the size of the firm and the age of the firm it is possible to establish good practices of Human Resource Management which contribute to provide the organization with a more appropriate and contended employee force that gives the maximum contribution to its success. It is likely that it does not matter that the firm has 100 employees or 1000 employees. It is likely that it does not matter that the firm's age is 10 years or 50 years. Human Resource Management is essential for any Organization and it is possible to practice good Human Resource Management practices. The systematic use of Human Resource Management practices can be made at higher degree despite the size of the firm and the age of the firm. In this context, top management support and employment of right personnel who specialize in HRM are arguably effective to enhance the systematic use of HRM practices in firms.

\section{References}

Armstrong, M. (1998), A Handbook of Personnel Management Practice, London: Kogan Page Ltd.

Aswathappa, A.(2003), Human Resources and Personnel Management, $4^{\text {th }}$ ed, New Delhi, McGrow-Hill.

Beach, D.S. (1985), The Management of People at Work, New York: Macmilan Publishing Company.

Bernardin, H. J. and Russell, J.E.A. (1993), Human Resource Management: An Experiential Approach, New York:McGraw-Hill, Inc.

David, 1984, Personnel Management, $4^{\text {th }}$ ed, New York, McGraw Hill. 
Dessler, G. (2005), Human Resource Management, $10^{\text {th }}$ ed, New Delhi: Prentice-Hall of India.

Glueck, W.F. (1978), Personnel: A diagnostic approach, Revised Edi, Texas: Business Publications Inc.

Glueck, W.F. (1979), Foundations of Personnel, Texas: Business Publications Inc.

Ivancevich, J.M. (1992). Human Resource Management, Boston: Irwin MaGraw-Hill.

Mathis, R.L. and Jackson, J.H. (2000), Human Resource Management, New York: SouthWestern College Publishing.

Mithani, D.M. and Opatha, H.H.D.N.P. (2000), "Towards Effective Worker Performance Evaluation: An Important issue for the New Millennium", Management Review, XII:1, January-June, pp. 39-50.

Noe, P. M. (1994), Human Resource Management: Gaining a competitive advantage, Burr Ridge: IRWIN.

Norusis, M.J. (1997), SPSS 7.5 Guide to Data Analysis, New Jersey: Prentice Hall.

Opatha, H.H.D.N.P. (1994), Employee Grievance Settlement Procedure: A Case Study of Two Corporations, Management Review, Faculty of Management Studies \& Commerce, University of Sri Jayewardenepura, Sri Lanka, 1,2: pp.53-60.

Opatha, H.H.D.N.P. (1995), Sewamandala Kalamanakaranaya (Personnel Management), Colombo: HK Printers.

Opatha, H.H.D.N.P. (2002), "Towards Effective Worker Grievance Handling: Some Reflections", Management Matters, The Journal of the Faculty of Management Studies, Rajarata University of Sri Lanka, 1:3, July, pp.7-19.

Opatha, H.H.D.N.P. (2005), “An Empirical Investigation of Union-related Factors contributing to Labour-Management Relationship in Manufacturing Firms in Sri Lanka, Sasin Journal of Management, Sasin Graduate Institute of Business Administration of Chulalongkorn University, Vol.11, No1, 2005, pp.85-102.

Opatha, H.H.D.N.P. and Mithani, D.M. (2000), Towards Employee Discipline Administration: Some Reflections, NMIMS Management Review, XII:2, JulyDecember.

Papalexandris, N. (1992), "A comparative study of human resource management in selected Greek and foreign-owned subsidiaries in Greece", as in Brewster, C \& Tyson, S. Edi, International Comparisons in Human Resource Management, London: Pitman.

Schuler, R.S. and Youngblood, B.S.A. (1986), Effective Personnel Management, $2^{\text {nd }}$ ed., New York: West Publishing Company.

Sekaran, U. (1999), Research Methods for Business, A Skill Building Approach, 3 edition,

New York: John Wiley \& Sons, Inc.

Werther, B. W. and Davis, K. (1994), Human Resources and Personnel Management, $4^{\text {th }}$ ed, New York: McGraw- Hill Book Company.

Zikmund, W.G. (2000), Business Research Methods, $6^{\text {th }}$ ed, Fort Worth: Harcourt Brace College Publishers. 


\section{Appendix}

Figure: 2 Dimensions and Elements of Recruitment

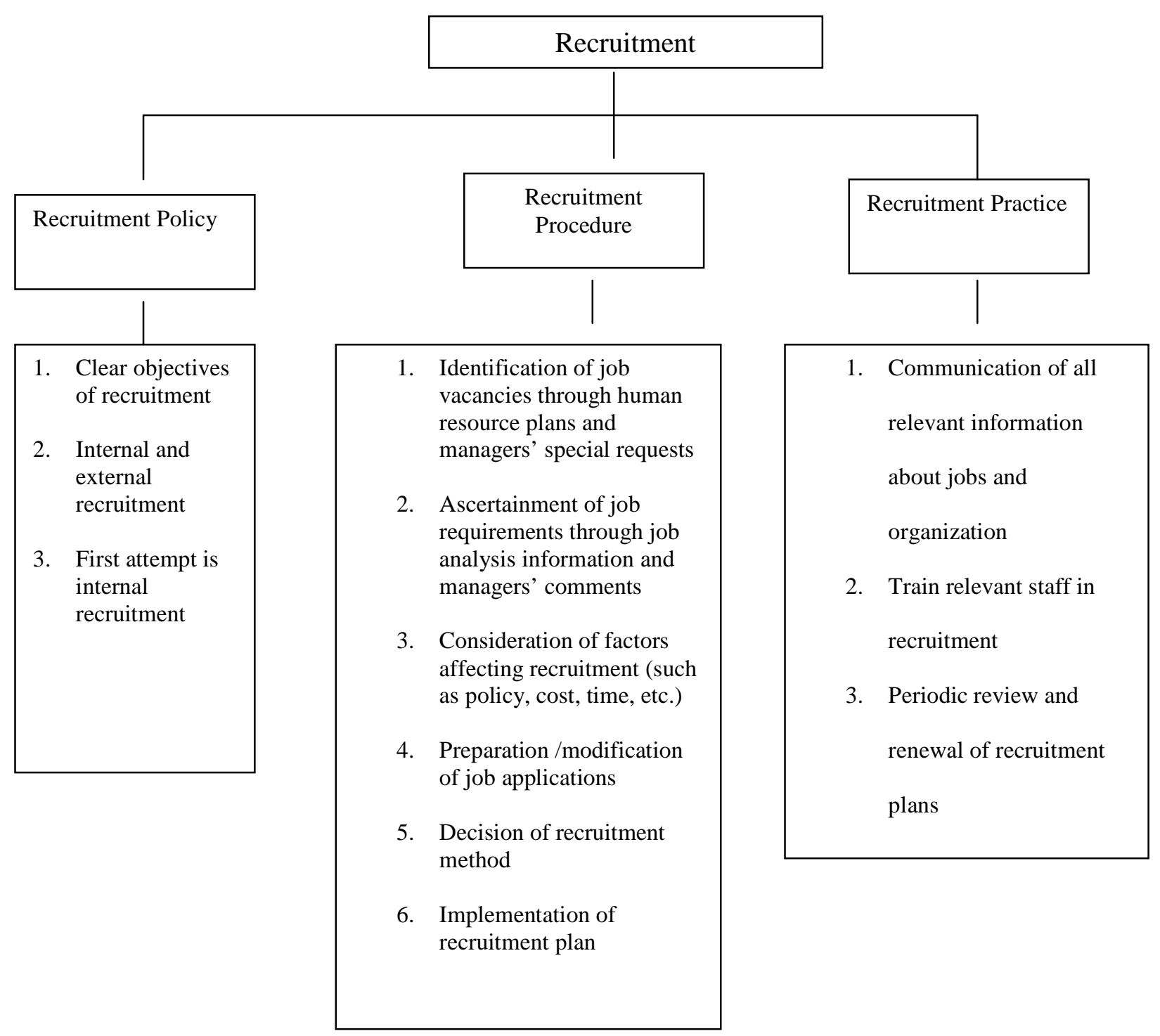


Figure: 3 Dimensions and Elements of Selection

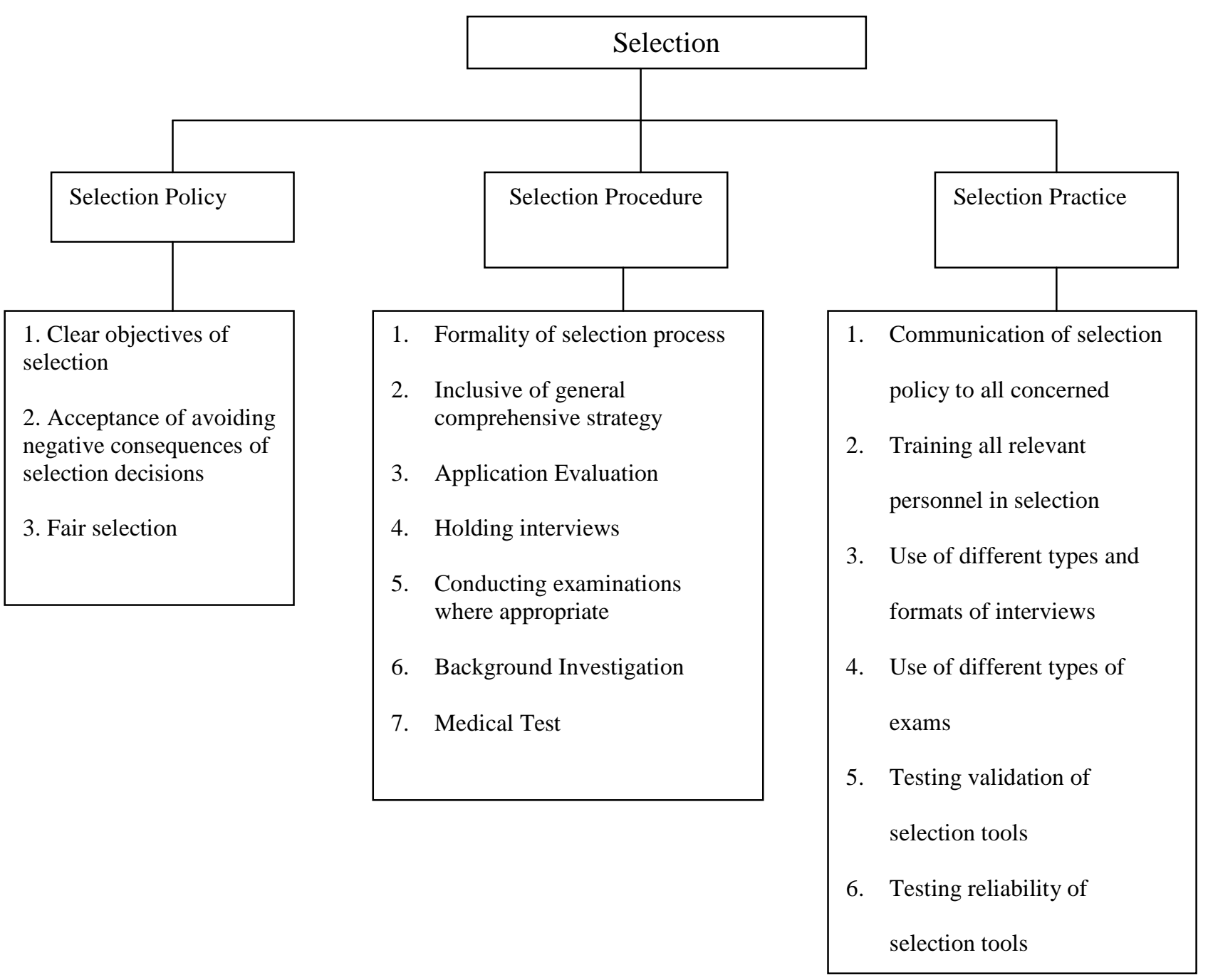


Figure: 4 Dimensions and Elements of Training and Development

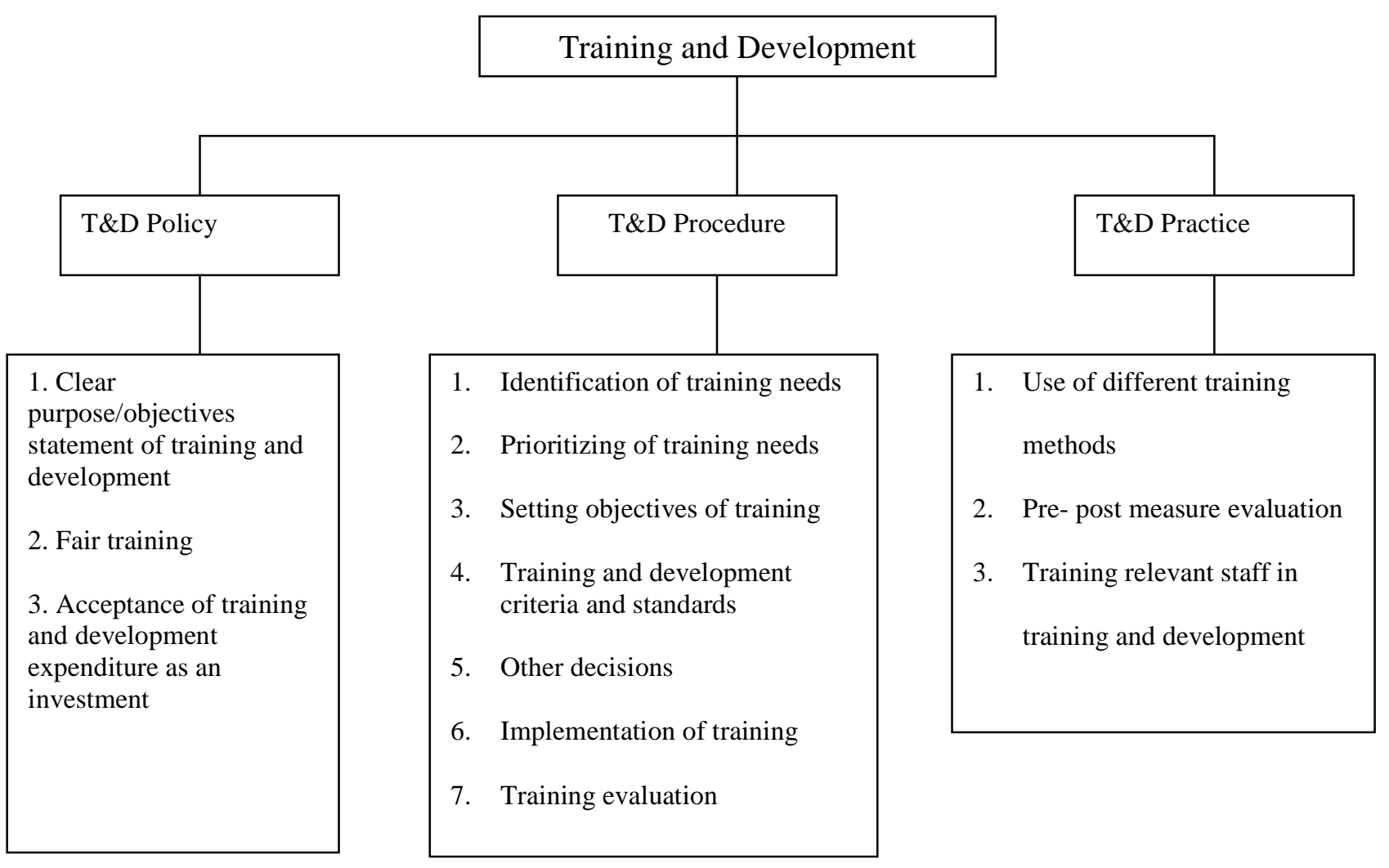


Figure: 5 Dimensions and Elements of Employee Performance Evaluation

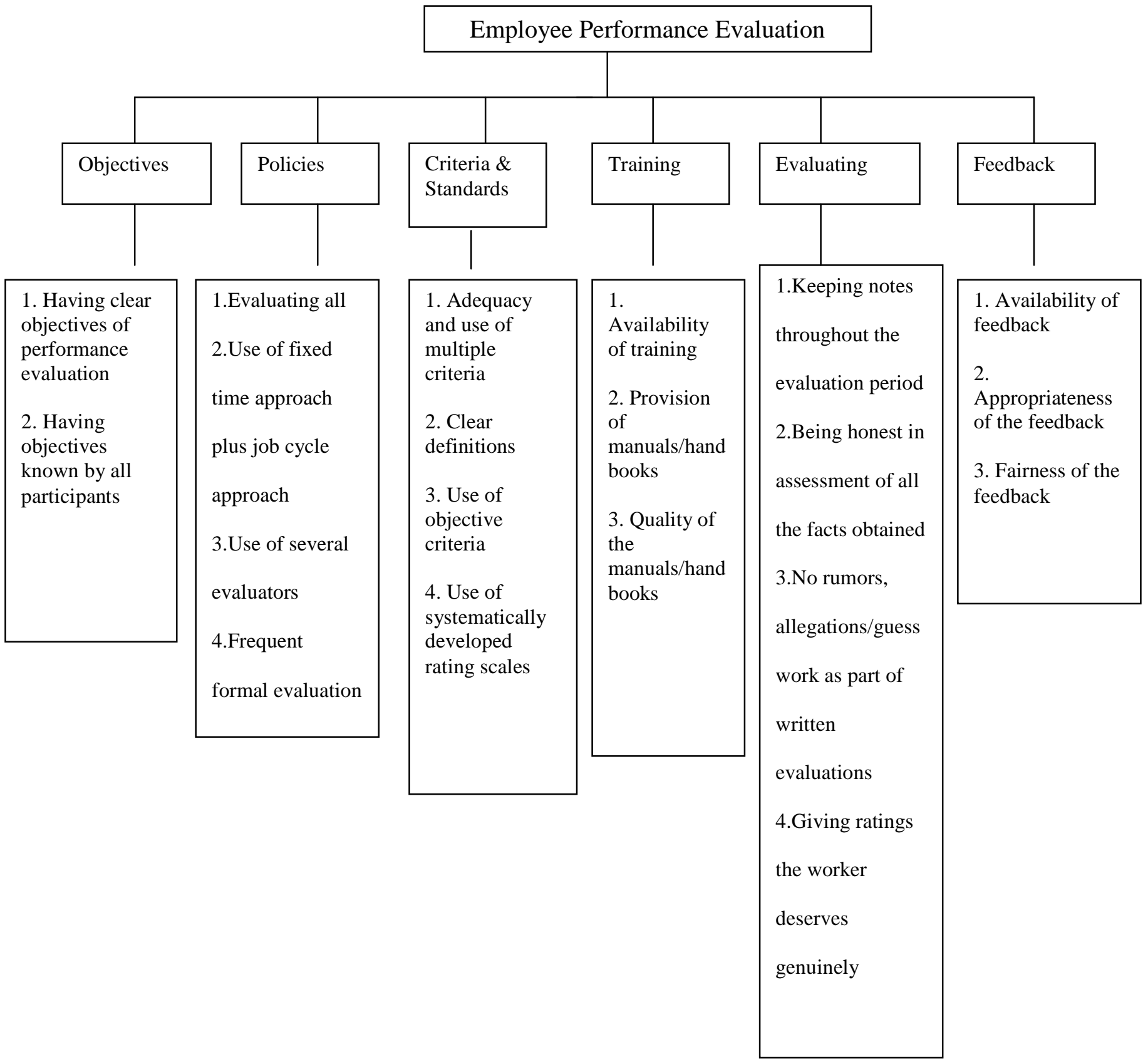

Source: Opatha (2005) 
Figure: 6 Dimensions and Elements of Grievance Handling

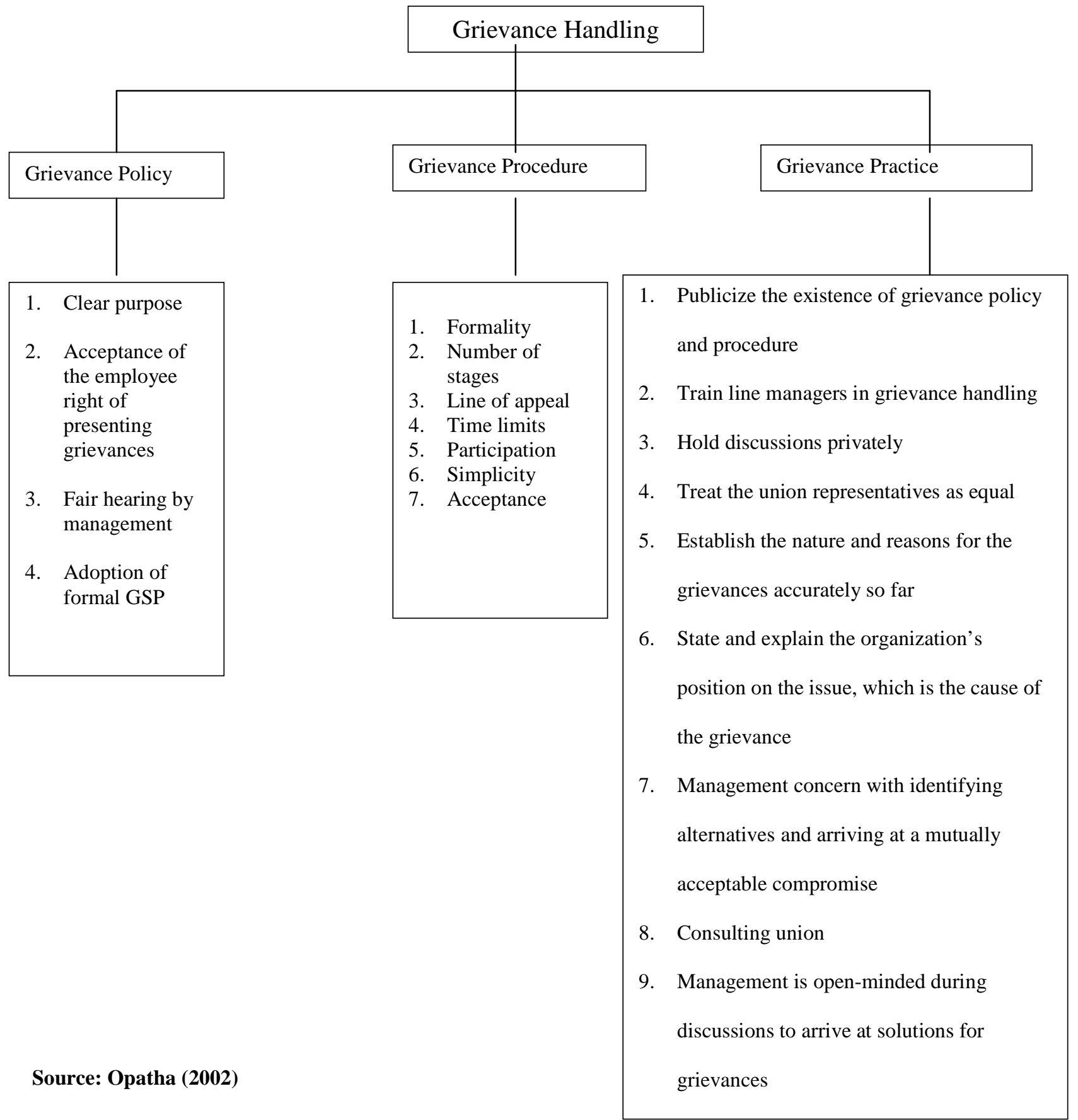


Figure: 7 Dimensions and Elements of Employee Discipline Administration

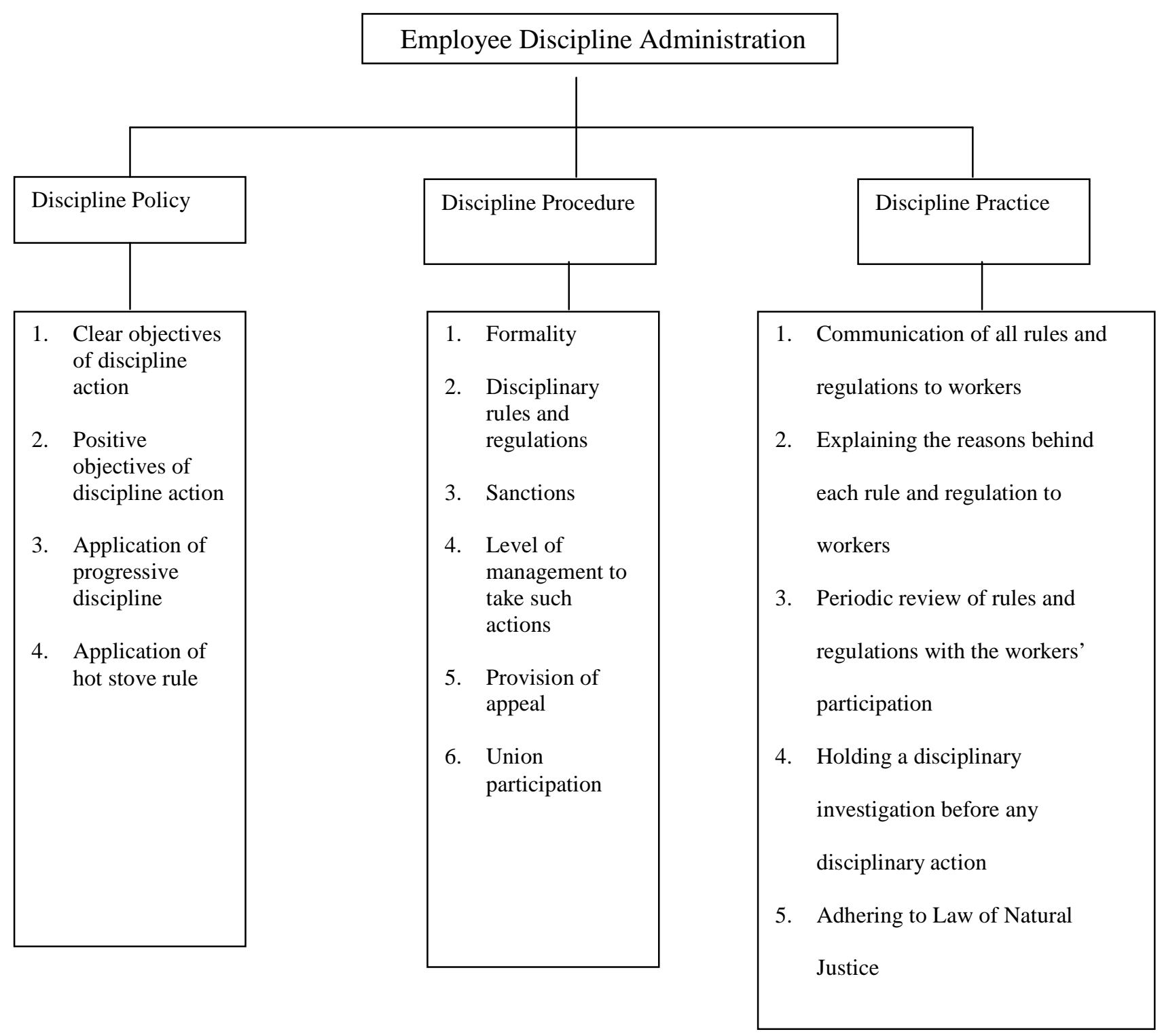

Source: Opatha and Mithani (2000) 